Article

\title{
Estimating Methane Emissions from a Dairy Farm Using a Computer Program
}

\author{
Bożena Nowakowicz-Dębek ${ }^{1}{ }^{\circledR}$, tukasz Wlazło $^{1}{ }^{\circledR}$, Agnieszka Szymula ${ }^{1}$, \\ Mateusz Ossowski ${ }^{1, * \mathbb{D}}$, Martyna Kasela ${ }^{2}$, Anna Chmielowiec-Korzeniowska ${ }^{1}$ \\ and Hanna Bis-Wencel ${ }^{1, *}$ \\ 1 Department of Animal Hygiene and Environmental Hazards, University of Life Sciences in Lublin, \\ Akademicka 13, 20-950 Lublin, Poland; bozena.nowakowicz@up.lublin.pl (B.N.-D.); \\ lukasz.wlazlo@up.lublin.pl (Ł.W.); agnieszka.szymula@wody.gov.pl (A.S.); \\ anna.korzeniowska@up.lublin.pl (A.C.-K.) \\ 2 Department of Pharmaceutical Microbiology, Medical University of Lublin, Chodźki 1, 20-093 Lublin, \\ Poland; martyna.kasela@umlub.pl \\ * Correspondence: mateusz.ossowski@student.up.edu.pl (M.O); hanna.biswencel@up.lublin.pl (H.B.-W.); \\ Tel.: +48-81-445-69-98 (M.O.); +48-81-445-69-52 (H.B.-W.)
}

Received: 30 May 2020; Accepted: 27 July 2020; Published: 30 July 2020

\begin{abstract}
The aim of our study was to estimate methane $\left(\mathrm{CH}_{4}\right)$ emissions from a dairy cattle farm using a computer application. Emissions of $\mathrm{CH}_{4}$ in the air were forecast for a representative dairy farm raising Holstein-Friesian cows. The cowshed was equipped with a mechanical forced ventilation system with a centrally located ventilation duct. The volume of emissions from the emitter was established, taking into account meteorological conditions. For one year of operation of the emitter, the average annual emission was $1.301 \mathrm{~kg} / \mathrm{h}$. The maximum emission of $\mathrm{CH}_{4}$ was estimated at $3.51 \mathrm{~kg} / \mathrm{h}$. These data can be helpful in estimating the environmental burden of a dairy farm and in determining the role of ruminants in global warming.
\end{abstract}

Keywords: methane emission; greenhouse gas; ruminant; computer modelling; global warming

\section{Introduction}

According to the Food and Agricultural Organization, the livestock sector generates more greenhouse gases (GHG), measured in $\mathrm{CO}_{2}$ equivalent, than the transport sector. Livestock farms, especially cattle farms, are among the main sources of emission of these gases. Emissions of methane $\left(\mathrm{CH}_{4}\right)$ and nitrous oxide $\left(\mathrm{N}_{2} \mathrm{O}\right)$ associated with animal production around the world account for about $9 \%$ of total $\mathrm{GHG}$ emissions. As a $\mathrm{GHG}, \mathrm{CH}_{4}$ has been recognized as an important factor in climate change. It is produced in the digestive tract of ruminants and during anaerobic digestion of waste as a by-product of the decomposition of organic matter [1,2]. The amount of $\mathrm{CH}_{4}$ produced in cow intestines is influenced by multiple factors, including the composition and balance of the diet, physiological differences between individuals, production level, and microclimatic conditions. Limiting the amount of $\mathrm{CH}_{4}$ released from metabolic transformations and adaptation of suitable measurement techniques continue to pose problems for researchers [1,3-7]. In a study by Eckert et al. [8], the $\mathrm{CH}_{4}$ emission rate estimated at milking stations was similar to that observed in cows in respiratory chambers. It was determined that owing to further validation of the method, monitoring of $\mathrm{CH}_{4}$ emissions on the farm during milking can provide an inexpensive and reliable method for estimating daily $\mathrm{CH}_{4}$ production by individual dairy cows. Respiration chambers are used for inventory purposes because they are widespread and easier than more detailed statistical methods. Hristov et al. [9] recommend simplified prediction models of enteric $\mathrm{CH}_{4}$ based on dry matter intake (DMI) for analysis of data for dairy cattle. 
In combination with data on the animals' diet, they can predict average $\mathrm{CH}_{4}$ emissions with a similar accuracy to complex empirical models. These simplified models can be used for emission inventory purposes [9]. Efforts are being made to develop a method to predict enteric $\mathrm{CH}_{4}$ emissions in dairy cows using Fourier-transform infrared spectroscopy or measurements based on gas chromatography of fatty acids from milk. Both techniques have potential, but cannot yet predict $\mathrm{CH}_{4}$ emissions in dairy cows in practice. Additional $\mathrm{CH}_{4}$ measurements are needed to improve the accuracy and reliability of specific spectra for predictive $\mathrm{CH}_{4}$ emissions [10]. According to Niu et al. [11], intestinal $\mathrm{CH}_{4}$ measurement on a large scale is costly and impractical, and therefore modelling is commonly used to predict $\mathrm{CH}_{4}$ production. The authors cited found the intercontinental model to work best. Prediction models of $\mathrm{CH}_{4}$ production, yield and intensity developed on an intercontinental basis were found to have similar performance in different regions. Conversion factors for $\mathrm{CH}_{4}$ must be modified for individual regions in order to improve emission estimates in individual countries. Information on DMI is required for a reliable forecast, and other factors, such as the neutral detergent fibre (NDF) concentration, provide more detail in these calculations for better $\mathrm{CH}_{4}$ release results. Some information on the production of enteric $\mathrm{CH}_{4}$ in dairy cows can be obtained by analyzing metabolite content in milk. These data have modest potential for predicting emissions of this gas [12]. Modelling of emissions of gaseous pollutants into the air is often the basis for administrative decisions for many farms. For this reason, suitable measurement methods and indicators are needed to calculate the actual emissions of this gas. The aim of this research was to estimate the level of $\mathrm{CH}_{4}$ emissions from a dairy cattle farm using a computer application.

\section{Materials and Methods}

Forecasting of $\mathrm{CH}_{4}$ emissions was carried out for a representative dairy cattle farm with a stocking density of 100 livestock unit (LSU). During the data collection, Holstein-Friesian dairy cows were kept on the farm. The average milk yield for the herd during the research period was about $8000 \mathrm{~L}$ of milk per lactation per cow. The animals were kept on slatted floors without litter in a free-stall system. The cattle are fed a total mixed ration (TMR) balanced for the production of $28 \mathrm{~kg}$ of milk per cow per day with uninterrupted access to drinking water. The remaining energy demand is met by individual feeding with concentrate feed in the robot during milking (Table 1). The average milk yield during the study period was 35-36 L per cow per day for 209 days of lactation. The feed ration was balanced to provide the appropriate amount of energy, protein, minerals and vitamins. The cows were kept indoors year-round. The barn was equipped with a forced mechanical ventilation system with a centrally located ventilation duct.

Table 1. Total mixed ration composition.

\begin{tabular}{cccc}
\hline Component & Dry Matter (\%) & Milk Production $\mathbf{( k g )}$ & Share of Dry Matter in TMR $\mathbf{( k g )}$ \\
\hline Maize silage & 36 & 24 & 6.8 \\
Alfalfa silage & 47 & 6.0 & 2.8 \\
Grass mixture (Lolium multiflorum, Trifolium & 37 & 4.0 & 1.5 \\
incarnatum L, Vicia villosa) & 22 & 10 & 2.2 \\
Brewer's grain & 24 & 7 & 1.7 \\
Sugar beet pulp & 0.0 & 4.0 & 0.0 \\
Water & 86 & 2.8 & 2.4 \\
Wheat meal & 88 & 2.5 & 2.2 \\
Rapeseed meal & 95 & 0.5 & 0.47 \\
Additive preventing heating of TMR & & & \\
\hline
\end{tabular}

The software used for the forecast was Operat FB, which is in compliance with the methodology given in the Regulation of the Minister of the Environment on the reference values of certain substances in the air [13]. The operating parameters of the emitter were determined according to the following formula:

$$
d r=\sqrt{\frac{4 p q}{\Pi}}
$$


where $p$ and $q$ are the dimensions of the rectangular emitter, and $d \mathrm{r}$ is the equivalent diameter.

For the purpose of data analysis, the following parameters were adopted as input data in the program: emitter height: $12 \mathrm{~m}$; diameter: $0.4 \mathrm{~m}$; gas temperature: $283 \mathrm{~K}$; and specific heat of gases: $1.30 \mathrm{~kJ} / \mathrm{m}^{3} / \mathrm{K}$. The effective height of the emitter $(H)$ was determined according to the following formula:

$$
H=h+\Delta h
$$

where the gas plume rise $(\Delta h)$ depends on the exit velocity of the gases $(v)$, heat emission $(Q)$ and wind speed at the height of the outlet of the emitter. The gas plume rise is determined based on the Holland formula $(0 \leq Q \leq 16,000 \mathrm{~kJ} / \mathrm{s})$, the CONCAWE formula $(Q \geq 24,000 \mathrm{~kJ} / \mathrm{s})$ and a combination of these formulas $(16,000<Q<24,000 \mathrm{~kJ} / \mathrm{s})$.

In accordance with the regulation on emissions [13], sub-periods were taken into account in calculating levels of substances in the air.

Modelling was carried out for two temperature periods-autumn/winter and spring/summer, with average annual temperatures of 275.1 and 278.1, respectively. The annual average temperature in the area for the entire year was $281.1 \mathrm{~K}$. The $\mathrm{CH}_{4}$ emission factor was $114 \mathrm{~kg} / \mathrm{cow} /$ year/LSU, which takes into account both enteric fermentation and feces. Sub-periods were established taking into account variability in emissions, with the specific parameters of the emitters, their simultaneous operation, and meteorological data. Wind rose data for the calculation of concentrations within the sensor network were obtained from a nearby meteorological station. They took into account the state of equilibrium of the atmosphere $(c)$ and the range of wind speed (wind rose). The aerodynamic roughness coefficient of the terrain $\left(z_{0}\right)$ was determined within $50 h_{\max }(F)$ by the following formula:

$$
z_{0}=\frac{1}{F} \sum_{c} F c \cdot z_{o c}
$$

The roughness of the terrain (topography), taking into account nearby buildings, tree stands and terrain relief, was set at $0.5 \mathrm{~m}$, which corresponds to low buildings [13].

The maximum concentration of the gaseous substance $\left(E_{g}\right)$ averaged for one hour $\left(S_{m}\right)$ in specific meteorological conditions ( $u$, wind speed) was calculated according to the following formula:

$$
S_{m}=C_{1} \frac{E_{g}}{u A B}\left(\frac{B}{H}\right)^{g} \cdot 1000\left[\mu \mathrm{g} / m^{3}\right]
$$

where $C_{1}$ and $g$ are dependent on the state of equilibrium of the atmosphere, $A$ is the horizontal diffusion coefficient and $B$ is the vertical diffusion coefficient. The following formulas were used to calculate the coefficients:

$$
\begin{gathered}
A=0.088 \cdot\left(6 m^{-0.3}+1-\ln \frac{H}{Z_{0}}\right) \\
B=0.38 m^{1.3} \cdot\left(8.7-\ln \frac{H}{H_{0}}\right)
\end{gathered}
$$

When calculating the levels of substances in the air, it was assumed that if the same substances are emitted from all the emitters on the farm, then the calculations are carried out for the complex of emitters.

There are no health resort areas at a distance of less than $30 x_{m m}$ from any of the emitters on the farm.

The average concentration of the gaseous substance $(\bar{S})$ on the surface of the area $(x$, distance from the emitter to the point) was calculated according to the formula included in the regulation, where $\overline{E_{g}}$ 
is the average emission of the substance, $\bar{u}$ is the average wind speed and $\sigma_{z}$ is the vertical diffusion coefficient [13]:

$$
\bar{S}=\frac{r}{\Pi \sqrt{2 \Pi}} \cdot \frac{\bar{E}_{g}}{\overline{\bar{u} \sigma_{z} x}} \exp \left(\frac{H^{2}}{2 \sigma_{z}^{2}}\right) \cdot 1000
$$

The frequency of exceedance of the reference value or the permissible level of the substance in the air for all meteorological conditions was determined using the formula with the software:

$$
P\left(D_{1}\right)=\sum_{j} P i
$$

When calculating the average annual concentration, in accordance with the regulation [13], the concentration values calculated for all meteorological conditions are added, taking into account their frequency at a given wind rose. The maximum concentration $S_{m m}$ is defined as the highest value from the set of all concentrations in various meteorological conditions. If the concentration caused by the emission of the substance from the emitters exceeds the permissible level of the substance in the air, the frequency of such exceedance is calculated. The frequency of exceedance of the reference value or permissible level of the substance in the air $\left(D_{1}\right)$ was calculated if the concentration values for buildings near the emitters exceeded $D_{1}$ or if the condition $S_{m m} \leq D_{1}$ was not met. These values are considered to be met for the pollutant if the frequency with which the average concentration exceeds $D_{1}$ for one hour is not more than $0.2 \%$ of the year. The FB Proeko OPERAT software package, which operates on these assumptions, was used to estimate the emission volume.

\section{Results}

The $\mathrm{CH}_{4}$ emissions from the analyzed site are presented in Table 2. For one year $(8760 \mathrm{~h})$ of operation of the emitter, the average annual emission was $1.301 \mathrm{~kg} / \mathrm{h}$, or $11.4 \mathrm{Mg} /$ year. The maximum emission of $\mathrm{CH}_{4}$ was estimated at $3.51 \mathrm{~kg} / \mathrm{h}$. Figures 1 and 2 show the distribution of maximum concentrations and average annual concentrations for $\mathrm{CH}_{4}$ around the site.

Table 2. Methane $\left(\mathrm{CH}_{4}\right)$ emissions to the atmosphere during the modelling period.

\begin{tabular}{cccccc}
\hline Symbol & Velocity of Gases & Temperature of Gases & Max Emissions & Average Annual Emissions & Annual Emissions \\
\hline \multirow{2}{*}{ E1 ${ }^{1}$} & \multirow{2}{*}{$0.4 \mathrm{~m} / \mathrm{s}$} & $283 \mathrm{~K}$ & $\begin{array}{c}3.51 \mathrm{~kg} / \mathrm{h} \\
975 \mathrm{mg} / \mathrm{s}\end{array}$ & $\begin{array}{c}1.301 \mathrm{~kg} / \mathrm{h} \\
361 \mathrm{mg} / \mathrm{s}\end{array}$ & $11.4 \mathrm{mg} / \mathrm{year}$ \\
\hline & & & 1 first emitter.
\end{tabular}

Depending on the roughness of the terrain and local microclimatic conditions, particularly wind movement, the range of concentrations of substances in the air is highly variable. Figure 3 shows the $\mathrm{CH}_{4}$ concentrations in the air around the emitter depending on wind velocity.

The highest maximum concentration was $1.089 \mathrm{mg} / \mathrm{m}^{3}$, which exceeds the permissible concentration $\left(D_{1}\right)$ of $\mathrm{CH}_{4}$ in the air averaged for one hour for the specified meteorological situation. Therefore, the distance of the maximum concentrations $\left(x_{m m}\right)$ was calculated and found to amount to $43.5 \mathrm{~m}$. To analyses the possibility of highly elevated concentration values, the area within a $1305 \mathrm{~m}$ radius of the emitter should be considered (Table 3).

\begin{tabular}{|c|c|c|c|c|c|}
\hline $\begin{array}{c}\text { Max Concentration } S_{m m} \\
{\left[\mathrm{mg} / \mathrm{m}^{3}\right]}\end{array}$ & $\begin{array}{c}\text { Acceptable Concentration } \\
D_{1}\left[\mu \mathrm{g} / \mathrm{m}^{3}\right]\end{array}$ & $\begin{array}{c}\text { Distance of Max } \\
\text { Concentration } X_{m m}[\mathrm{~m}]\end{array}$ & $\begin{array}{l}\text { Critical State } \\
\text { of Equilibrium }\end{array}$ & $\begin{array}{l}\text { Critical Wind } \\
\text { Velocity }[\mathrm{m} / \mathrm{s}]\end{array}$ & $\begin{array}{c}\text { Evaluation of Concentrations } \\
\text { at Ground Level }\end{array}$ \\
\hline 1.089 & 3000 & 43.5 & 4 & 1 & $0.1 \times D_{1}<S_{m m}<D_{1}$ \\
\hline
\end{tabular}

Table 3. Methane $\left(\mathrm{CH}_{4}\right)$ emissions to the atmosphere during the modelling period. 


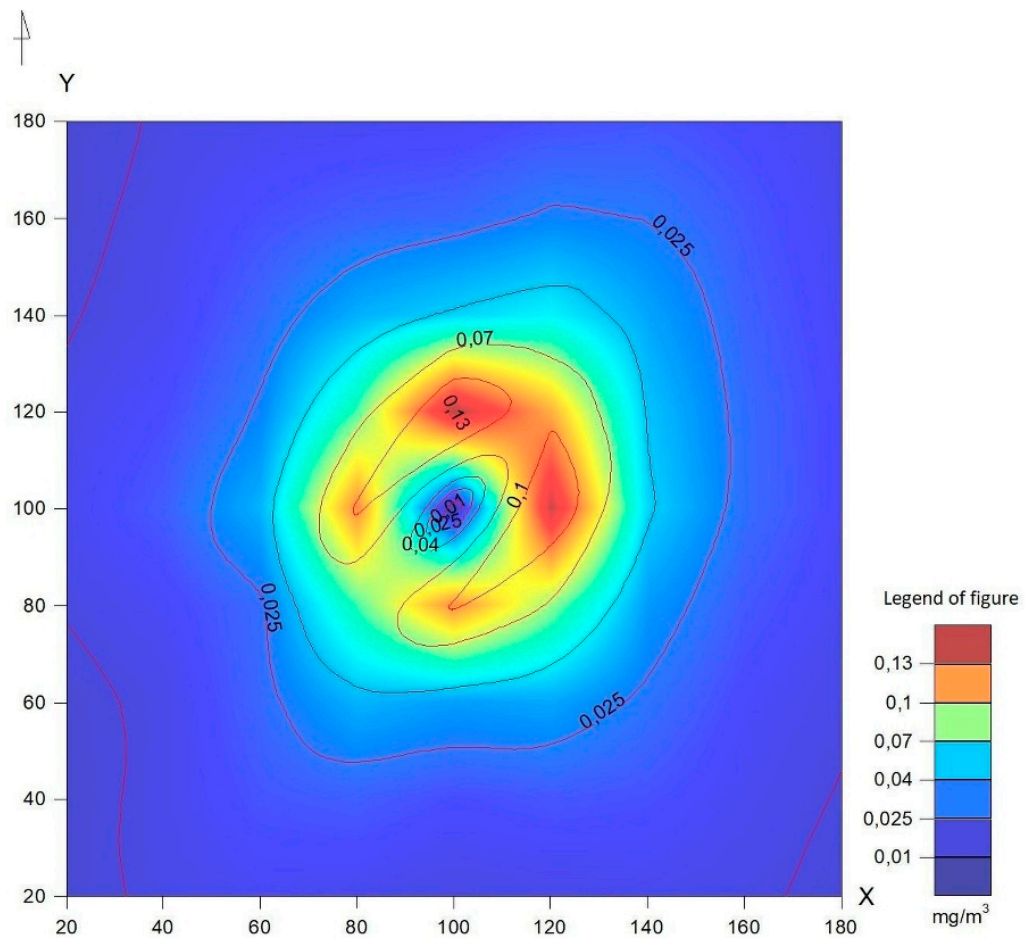

Figure 1. Maximum concentrations for methane $\left(\mathrm{CH}_{4}\right)$ emissions at a height of $10 \mathrm{~m}$. Note: $\mathrm{X}$ axis-component of the distance from the emitter to the point for which the calculations were made, parallel to the wind direction; $\mathrm{Y}$ axis-component of the distance from the emitter to the point for which the calculations were made, perpendicular to the wind direction.

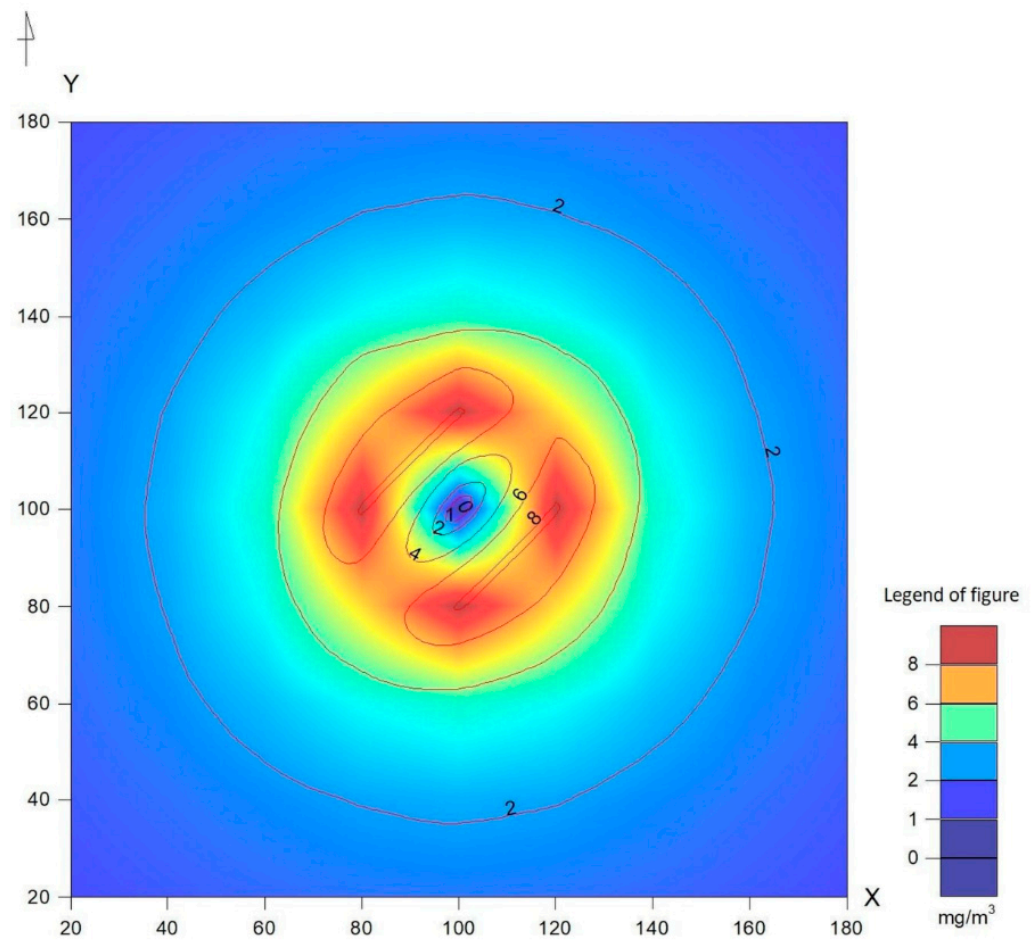

Figure 2. Average annual concentrations for methane $\left(\mathrm{CH}_{4}\right)$ emissions at a height of $10 \mathrm{~m}$. Note: $\mathrm{X}$ axis-component of the distance from the emitter to the point for which the calculations were made, parallel to the wind direction; $\mathrm{Y}$ axis—component of the distance from the emitter to the point for which the calculations were made, perpendicular to the wind direction. 


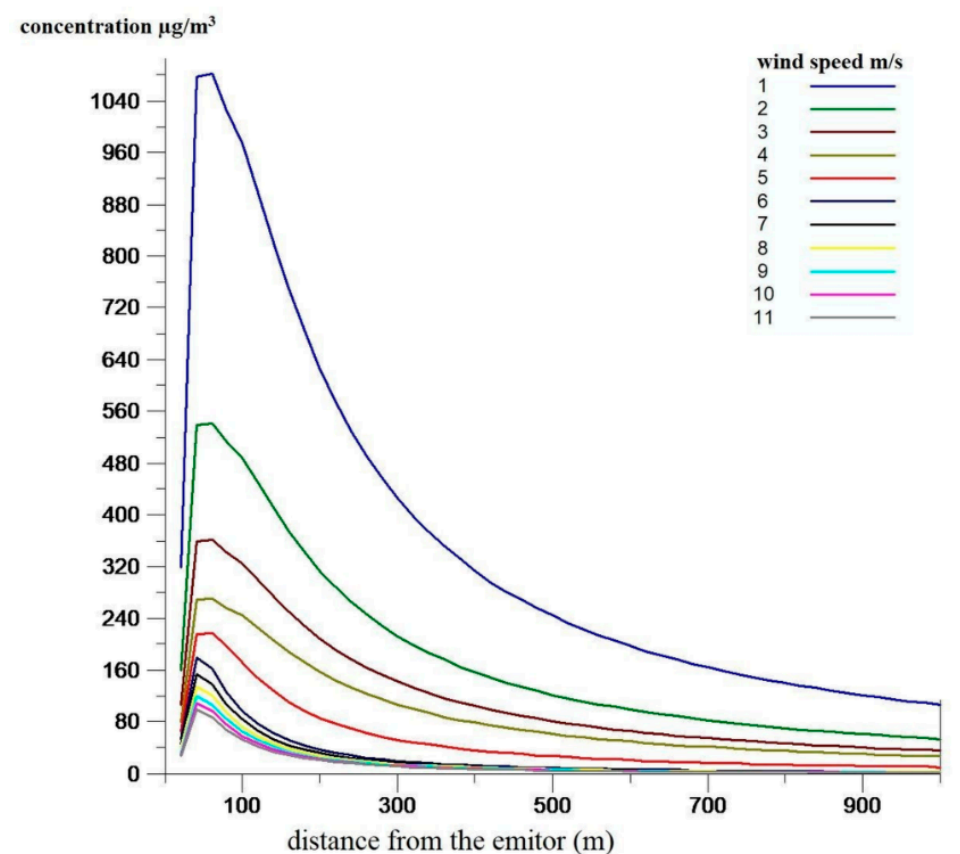

Figure 3. Variation in concentrations at various distances from the emitter depending on wind strength at ground level.

The concentrations calculated for the network of sensors at the height of $10 \mathrm{~m}$ exceeded the maximum allowable concentration of $3000 \mu \mathrm{g} / \mathrm{m}^{3}$ (Table 4). The analysis showed that the reference value was exceeded at 8 of 81 analyzed sensor points. To illustrate the distribution of pollutants, the frequency of exceedances is presented in Figure 4.

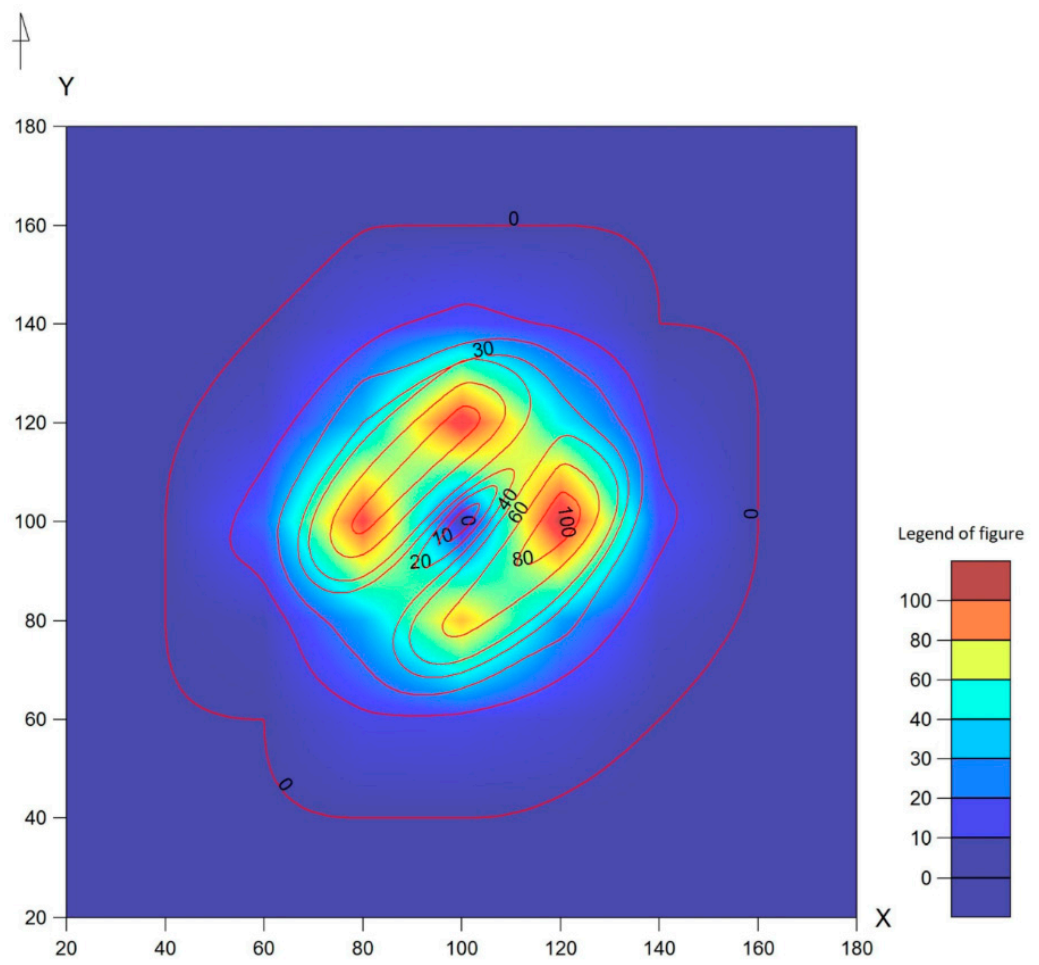

Figure 4. Frequency of exceedances in the network of sensors at a height of $10 \mathrm{~m}$. 
Table 4. Calculated concentrations of aliphatic hydrocarbons in the network of sensors at a height of $10 \mathrm{~m}$.

\begin{tabular}{|c|c|c|c|c|c|c|c|}
\hline$X$ & $\mathbf{Y}$ & $\begin{array}{l}\text { Max Concentration } \\
\left(\mathrm{mg} / \mathrm{m}^{3}\right)\end{array}$ & $\begin{array}{l}\text { Average Concentration } \\
\qquad\left(\mathrm{mg} / \mathrm{m}^{3}\right)\end{array}$ & $\begin{array}{l}\text { Critical State of } \\
\text { Equilibrium }\end{array}$ & $\begin{array}{l}\text { Critical Wind } \\
\text { Velocity }\end{array}$ & $\begin{array}{l}\text { Critical Wind } \\
\text { Direction }\end{array}$ & $\begin{array}{c}\text { Frequency of Exceedances } \\
(\%) \\
\mathrm{mg} / \mathrm{m}^{3}\end{array}$ \\
\hline 80 & 80 & 5.5 & 0.063 & 6 & 1 & NNE & 0.30 \\
\hline 100 & 80 & 8.2 & 0.103 & 6 & 1 & $\mathrm{~N}$ & 0.82 \\
\hline 120 & 80 & 5.5 & 0.070 & 6 & 1 & NNW & 0.28 \\
\hline 80 & 100 & 8.2 & 0.104 & 6 & 1 & E & 1.03 \\
\hline 120 & 100 & 8.2 & 0.129 & 6 & 1 & W & 1.15 \\
\hline 80 & 120 & 5.5 & 0.063 & 6 & 1 & SSE & 0.34 \\
\hline 100 & 120 & 8.2 & 0.132 & 6 & 1 & S & 1.08 \\
\hline 120 & 120 & 5.5 & 0.096 & 6 & 1 & SSW & 0.41 \\
\hline
\end{tabular}

\section{Discussion}

Determination of the actual levels of GHG emissions is an essential element of the continuous improvement of European legal regulations: Integrated Pollution Prevention and Control (IPPC) and National Emission Ceilings (NEC) directives, and calculation of the acceptable CO2 equivalent limit for individual Member States [14,15]. Many models of GHG emissions from dairy production systems have been developed. These include fixed emission factors, variable emissions associated with herd management, and empirical or statistical models. Each of them can be very effective when used properly. Detailed simulation models of emission processes provide essential research tools, while simpler models are usually most useful as support for the issuing of environmental decisions. The Gaussian model used in our research is similar to the model of an integrated agricultural system based on gas emission factors [16]. Many authors perform regression analysis as a model in determining emissions, because it is used to estimate the relationship between a dependent variable and one or more descriptive variables. Regression analysis can be used to model the relationship between selected variables, as well as to predict values based on a specific model [17]. In our study, we used the Gaussian model (plume or cloud), which is a two-step deterministic model. Modelling of meteorological fields is carried out first, followed by modelling of the dispersion of pollution. The emission factor used makes it possible to obtain the distribution of the concentration of $\mathrm{CH}_{4}$ isolines in the area. This model, while providing information on the total amount of $\mathrm{CH}_{4}$ emitted from the farm, cannot be used to determine the factors affecting this value. Among the available strategies for mitigating the environmental impact of dairy farms, increasing attention is being paid to the genetic factor. $\mathrm{CH}_{4}$ emissions have been found to differ significantly between dairy cows kept on the same farm. This variation should be taken into account when conducting inventory or testing mitigation strategies, but it may offer genetic selection options, while $\mathrm{CH}_{4}$ emission rates can be obtained using $\mathrm{CH}_{4}$ analyzers installed in automatic (robotic) milking stations [18]. However, based on the concentration of pollutants and atmospheric conditions, dispersion models can be created to simulate their dispersion and estimate their concentrations at any distance from the source. The majority of legal regulations regarding emissions of pollutants, including odors, are currently created on this basis. However, the minimum distances specified in them between the source of emissions and the residential area give rise to serious discussions among both producers and residents. Such models provide important tools for quantifying emissions, determining the possibility of reducing them, and selecting strategies to mitigate the impact of the farm on the environment $[19,20]$. The amount of gases emitted by dairy cows is closely correlated with the protein value of their diet, as well as the animal's physiological state during milk production. $\mathrm{The}^{\mathrm{CH}} \mathrm{H}_{4}$ content in the gases excreted by cows is about $25 \%$. This amounts to about $1000-1300 \mathrm{~L}^{\circ} \mathrm{CH}_{4}$ per cow per day. According to the literature data, one cow emits $112 \mathrm{~kg}$ of $\mathrm{CH}_{4}$ and $40 \mathrm{~kg}$ of ammonia a year [21], which is consistent with our own modelling results obtained using a computer application. Several systems have been developed for estimating $\mathrm{CH}_{4}$ emissions from dairy farms. In vitro testing of production of this gas most often involves incubation of rumen inoculum under anaerobic conditions in special jars. The quantities of gas generated during this time are subjected to chromatographic analysis and calculated using calibration curves [22]. Individual $\mathrm{CH}_{4}$ and $\mathrm{CO}_{2}$ production was registered during milking in an automatic milking system (AMS) to estimate individual differences in $\mathrm{CH}_{4}$ production 
between cows. Measurements based on Fourier-transform infrared (FTIR) detection showed that gas emissions were positively correlated with consumption of concentrate feed but were not dependent on the cow's milk yield. The repeatability of the results for the $\mathrm{CH}_{4}$ and $\mathrm{CO}_{2}$ ratio was 0.39 for the Holstein breed and 0.34 for Jerseys. The results suggest that the ratio of $\mathrm{CH}_{4}$ and $\mathrm{CO}_{2}$ measured by this non-invasive method is an individual feature of cows and can be useful both in herd management and in genetic assessments of predisposition to enteric $\mathrm{CH}_{4}$ production [23].

Another method is to analyses the composition of the feed ration and the content of protein substances that can be converted to $\mathrm{CH}_{4}$ as a result of digestive processes. The feed analysis method uses the composition of the animal diet and calculated nutrient digestibility. According to Tomkins et al. [24], the results of these calculations may vary by up to $35 \%$. This is due to the variable composition of feed and its intake by animals. Feed experiments require many repetitions to capture changes in individual parameters, as well as seasonal influences and the availability and quality of feed. Using this method, the most accurate data can be obtained with a respiration chamber, but the data pertain to individual animals. Although they can provide accurate data on the chemical composition of the air inside the chamber, there is a risk of changes in feed intake by the animal due to stress as well as losses of gas due to improper sealing of the chamber $[15,24,25]$. The high costs associated with the construction and maintenance of respiration chambers significantly limit the use of this method. For scientific purposes, estimation of individual emissions is still applied, especially in the search for gas reduction methods [15]. Recent research in dairy cattle has revealed hereditary variation in $\mathrm{CH}_{4}$ production that enables the use of strategies based on selective breeding. The results indicate that $\mathrm{CH}_{4}$ production is a trait highly correlated with the genotype of individual cattle. Studies show that the numbers of some bacteria and archaea in the cow's stomach are hereditary and associated with $\mathrm{CH}_{4}$ production, but most changes in the relative numbers of bacteria and archaea in the rumen are due to non-genetic factors. The degree of variation in $\mathrm{CH}_{4}$ production is therefore linked to the genetics of the host as well as the number of rumen bacteria and archaea. In this way, host genetics were determined to account for $21 \%$ of $\mathrm{CH}_{4}$ production, and rumen microbes for $13 \%$ [26,27]. Research by Van Engelen et al. [28] indicates that reduction can be achieved through selective breeding. The authors conducted research on genetic variability and $\mathrm{CH}_{4}$ emissions by Dutch Holstein-Friesian cows using infrared sensors installed in automatic milking systems. A 33\% reduction in $\mathrm{CH}_{4}$ emissions was found after 50 weeks of lactation. The authors recommend including the lactation stage in the $\mathrm{CH}_{4}$ emission analysis model. Pszczola et al. [29] indicate that $\mathrm{CH}_{4}$ emission is a hereditary trait and that the level of heritability changes during lactation. The changes observed and the low genetic correlations between days of lactation suggest that this may be an important element in determining emissions.

Calculation of the total emission of gases from livestock production, with reference to the NEC directive, requires a mathematical computation model using emission factors. These are helpful tools for estimating emissions of gaseous pollutants from farms. However, they do not take into account processes affecting the spread of gases and accompanying factors, e.g., diet modification. Computer simulations can provide a cost-effective and efficient method for estimating $\mathrm{CH}_{4}$ emissions on dairy farms. The program used was based on the classic Gaussian Model using Pasquill's equation, which is most commonly used in practice. The basic assumption resulting in Gaussian equations is that the distribution of pollutant concentrations in the plume is consistent with the Gaussian distribution, and the concentration fields are obtained for a specific time. In estimating the uncertainty of the modelling of emissions of pollutants, a fundamental limitation is the accuracy of the model of their dispersion in the environment. It includes accurate and verifiable input data, taking into account the physical and chemical characteristics of the pollutant and the terrain relief of the area. The result of the modelling, presented as a percentile of exceedances of the distribution, is burdened with the greatest uncertainty of measurement at the peak values of the Gaussian distribution, and the uncertainty decreases with the percentile values. It is typically accepted that when good input data are used, dispersion Gaussian modelling can be used to predict concentrations within a factor of two $[30,31]$. They are very useful for developing management systems that can minimize emissions. 
Herd management scenarios using computer models similar to that used in our own research have been developed by the Agricultural Research Service (ARS) of the US Department of Agriculture. An analysis carried out using the Integrated Farm System Model (IFSM) for a representative cattle farm in Pennsylvania with 100 cows forecast a total annual average emission level of $20 \mathrm{Mg} \mathrm{CH}$. This represented an average annual emission of $135 \mathrm{~kg} \mathrm{CH}_{4}$ per Holstein cow and an average emission of $5.4 \mathrm{~kg} \mathrm{CH} 4 / \mathrm{m}^{3}$ of stored slurry manure [14,32]. The results were very similar to those presented in our own research on $\mathrm{CH}_{4}$ emissions from dairy farms, confirming that computer models are effective in this type of analysis.

The introduction of good management practices on a farm can reduce emissions of this gas and improve profitability. The use of feed additives, as in the case of other animal species, may reduce the burden on the environment [4,28,33-37]. Not all GHG emissions are included in the Emission Trading Scheme (ETS). Non-ETS emissions include emissions from agriculture and households. According to the European Union Emission Trading System (EU ETS), the volume of emissions classified as non-ETS accounts for $55 \%$ of total emissions. Individual countries are granted limits on non-ETS in individual sectors. The problem of $\mathrm{CH}_{4}$ emissions is an important issue in milk production and is continually taken up in research $[38,39]$.

The presented data indicate that $\mathrm{CH}_{4}$ released from cattle farms poses a real threat to the natural environment. At the same time, gaseous pollutants spread along with it may be a source of odor nuisance, leading to complaints among local residents. The use of a computer application before beginning an investment, or even modernizing one, can be helpful in assessing its impact on the environment. The proposed model can also be effectively used in a $\mathrm{CH}_{4}$ emission reduction strategy, e.g., through the use of natural feed additives, or utilization of $\mathrm{CH}_{4}$ for energy purposes. Calculation of the $\mathrm{CH}_{4}$ concentration in the environment and knowledge of its energy value enable catalytic oxidation, which will provide a source of energy for farmers while at the same time reducing $\mathrm{CH}_{4}$ emissions. The data presented above indicate the need to monitor $\mathrm{CH}_{4}$ levels and find safe technologies to reduce the impact of this sector on global climate change.

\section{Conclusions}

The method described above for forecasting $\mathrm{CH}_{4}$ emissions from a farm is an easy way to determine its environmental burden. Owing to the low cost and simplicity of the program, we can quickly obtain information regarding the volume of $\mathrm{CH}_{4}$ emissions from a farm, taking into account the number of animals and the conditions prevailing around the site. These data can be helpful in estimating the environmental burden of the farm, finding means to neutralize pollutants, and determining the contribution of ruminants to global warming.

Author Contributions: Conceptualization, B.N.-D., Ł.W. and A.S.; methodology, Ł.W., B.N.-D. and A.S.; software, A.C.-K. and M.K.; validation, B.N.D., Ł.W. and M.O.; formal analysis, A.C.-K. and M.K.; investigation, Ł.W., B.N.-D. and M.O.; resources, M.O. and A.C.-K.; data curation, B.N.-D., Ł.W. and A.S.; writing-original draft preparation, B.N.-D., Ł.W. and H.B.-W.; writing-review and editing, Ł.W., M.O. and M.K.; visualization, B.N.-D., A.S. and H.B.-W.; supervision, B.N.-D., Ł.W. and A.S.; project administration, B.N.-D. and Ł.W.; funding acquisition, B.N.-D. and $Ł . W$. All authors have read and agreed to the published version of the manuscript.

Funding: This research received no external funding.

Conflicts of Interest: The authors declare no conflict of interest.

\section{References}

1. Kolasa-Więcek, A. Regression modeling of agrriculture greenhouse gases emissions in Poland. Ecol. Chem. Eng. A 2012, 19, 1383-1391.

2. Van Gastelen, S.; Dijkstra, J. Prediction of methane emission from lactating dairy cows using milk fatty acids and mid-infrared spectroscopy. J. Sci. Food Agric. 2016, 96, 3963-3968. [CrossRef] 
3. Bhatt, R.S.; Sahoo, A.; Kumar Soni, L.; Sharma, P. Methane emission, nutrient utilization, microbial protein synthesis and growth performance in finisher lambs fed complete feed blocks containing phytochemical-rich forages of semi-arid region. Carbon Manag. 2020, 11, 97-107. [CrossRef]

4. Knapp, J.R.; Laur, G.L.; Vadas, P.A.; Weiss, W.P.; Tricarico, J.M. Invited review: Enteric methane in dairy cattle production: Quantifying the opportunities and impact of reducing emissions. J. Dairy Sci. 2014, 97, 3231-3261. [CrossRef] [PubMed]

5. Ungerfeld, E.M. Inhibition of rumen methanogenesis and ruminant productivity: A meta-analysis. Front. Vet. Sci. 2018, 5, 113. [CrossRef] [PubMed]

6. Olijhoek, D.W.; Løvendahl, P.; Lassen, J.; Hellwing, A.L.F.; Höglund, J.K.; Weisbjerg, M.R.; Noel, S.J.; McLean, F.; Højberg, O.; Lund, P. Methane production, rumen fermentation, and diet digestibility of Holstein and Jersey dairy cows being divergent in residual feed intake and fed at 2 forage-to-concentrate ratios. J. Dairy Sci. 2018, 101, 9926-9940. [CrossRef] [PubMed]

7. Lan, W.; Yang, C. Ruminal methane production: Associated microorganisms and the potential of applying hydrogen-utilizing bacteria for mitigation. Sci. Total Environ. 2019, 654, 1270-1283. [CrossRef] [PubMed]

8. Eckert, M.; Bell, M.; Potterton, S.; Craigon, J.; Saunders, N.; Wilcox, R.; Hunter, M.; Goodman, J.; Garnsworthy, P. Effect of feeding system on enteric methane emissions from individual dairy cows on commercial farms. Land 2018, 7, 26. [CrossRef]

9. Hristov, A.N.; Kebreab, E.; Niu, M.; Oh, J.; Bannink, A.; Bayat, A.R.; Boland, T.M.; Brito, A.F.; Casper, D.P.; Crompton, L.A.; et al. Symposium review: Uncertainties in enteric methane inventories, measurement techniques, and prediction models. J. Dairy Sci. 2018, 101, 6655-6674. [CrossRef] [PubMed]

10. Van Gastelen, S.; Mollenhorst, H.; Antunes-Fernandes, E.C.; Hettinga, K.A.; van Burgsteden, G.G.; Dijkstra, J.; Rademaker, J.L.W. Predicting enteric methane emission of dairy cows with milk Fourier-transform infrared spectra and gas chromatography-based milk fatty acid profiles. J. Dairy Sci. 2018, 101, 5582-5598. [CrossRef]

11. Niu, M.; Kebreab, E.; Hristov, N.; Oh, J.; Arndt, C.; Bannink, A.; Bayat, A.R.; Brito, A.F.; Boland, T.; Casper, D.; et al. Prediction of enteric methane production, yield, and intensity in dairy cattle using an intercontinental database. Glob. Chang. Biol. 2018, 24, 3368-3389. [CrossRef] [PubMed]

12. Van Gastelen, S.; Antunes-Fernandes, E.C.; Hettinga, K.A.; Dijkstra, J. The relationship between milk metabolome and methane emission of Holstein Friesian dairy cows: Metabolic interpretation and prediction potential. J. Dairy Sci. 2018, 101, 2110-2126. [CrossRef] [PubMed]

13. Regulation of the Minister of the Environment of 26 January 2010 on Reference Values for Certain Substances in the Air. J. Laws 2010. Available online: http://prawo.sejm.gov.pl/isap.nsf/DocDetails.xsp?id= WDU20100160087 (accessed on 28 April 2019).

14. Directive (EU) 2016/2284 of the European Parliament and of the Council of 14 December 2016 on the Reduction of National Emissions of Certain Atmospheric Pollutants, Amending Directive 2003/35/EC and Repealing Directive 2001/81/EC. Available online: https:/eur-lex.europa.eu/legal-content/EN/TXT/HTML/?uri=CELEX: 32016L2284\&from=EN (accessed on 5 December 2019).

15. Goopy, J.P.; Chang, C.; Tomkins, N. A Comparison of methodologies for measuring methane emissions from ruminants. In Methods for Measuring Greenhouse Gas Balances and Evaluating Mitigation Options in Smallholder Agriculture; Rosenstock, T.S., Rufino, M.C., Butterbach-Bahl, K., Wollenberg, E., Richards, M., Eds.; Springer: Cham, Switzerland, 2016; pp. 97-117.

16. Rotz, C.A. Modeling greenhouse gas emissions from dairy farms. J. Dairy Sci. 2018, 101, 6675-6690. [CrossRef]

17. Fischer, T.M.; Gilmour, A.R.; Van der Werf, J.H. Computing approximate standard errors for genetic parameters derived from random regression models fitted by average information REML. Genet. Sel. Evol. 2004, 36, 1-8. [CrossRef] [PubMed]

18. Garnsworthy, P.C.; Craigon, J.; Hernandez-Medrano, J.H.; Saunders, N. Variation among individual dairy cows in methane measurements made on farm during milking. J. Dairy Sci. 2012, 95, 3181-3189. [CrossRef]

19. Sheridan, B.A.; Hayes, E.T.; Curran, T.P.; Dodd, V.A. A dispersion modelling approach to determining the odour impact of intensive pig production units in Ireland. Bioresour. Technol. 2004, 91, 145-152. [CrossRef]

20. Sarkar, U.; Hobbs, S.E.; Longhurst, P. Dispersion of odour: A case study with a municipal solid waste landfill site in North London, United Kingdom. J. Environ. Manag. 2003, 68, 153-160. [CrossRef]

21. Podkówka, Z.; Podkówka, W. Emisja gazów cieplarnianych przez krowy. Przeglad Hodowlany 2011, 3, 1-4. (In Polish) 
22. Ahring, B.K.; Murali, N.; Srinivas, K. Fermentation of cellulose with a mixed microbial rumen culture with and without methanogenesis. Ferment. Technol. 2018, 7, 152. [CrossRef]

23. Lassen, J.; Løvendahl, P.; Madsen, J. Accuracy of noninvasive breath methane measurements using Fourier transform infrared methods on individual cows. J. Dairy Sci. 2012, 95, 890-898. [CrossRef]

24. Tomkins, N.W.; McGinn, S.M.; Turner, D.A.; Charmley, E. Comparison of open-circuit respiration chambers with a micrometeorological method for determining methane emissions from beef cattle grazing a tropical pasture. Anim. Feed Sci. Technol. 2011, 166, 240-247. [CrossRef]

25. Jonker, A.; Hickey, S.M.; Rowe, S.J.; Janssen, P.H.; Shackell, G.H.; Elmes, S.; Bain, W.E.; Wing, J.; Greer, G.J.; Bryson, B.; et al. Genetic parameters of methane emissions determined using portable accumulation chambers in lambs and ewes grazing pasture and genetic correlations with emissions determined in respiration chambers. J. Anim. Sci. 2018, 96, 3031-3042. [CrossRef] [PubMed]

26. Difford, G.F.; Plichta, D.R.; Løvendahl, P.; Lassen, J.; Noel, S.J.; Højberg, O.; Wright, A.D.G.; Zhu, Z.; Kristensen, L.; Nielsen, H.B.; et al. Host genetics and the rumen microbiome jointly associate with methane emissions in dairy cows. PLoS Genet. 2018, 14, e1007580. [CrossRef] [PubMed]

27. Pszczola, M.; Strabel, T.; Mucha, S.; Sell-Kubiak, E. Genome-wide association identifies methane production level relation to genetic control of digestive tract development in dairy cows. Sci. Rep. 2018, 8, 1-11. [CrossRef]

28. Van Engelen, S.; Bovenhuis, H.; Van der Tol, P.P.J.; Visker, M.H.P.W. Genetic background of methane emission by Dutch Holstein Friesian cows measured with infrared sensors in automatic milking systems. J. Dairy Sci. 2018, 101, 2226-2234. [CrossRef]

29. Pszczola, M.; Rzewuska, K.; Mucha, S.; Strabel, T. Heritability of methane emissions from dairy cows over a lactation measured on commercial farms. J. Anim. Sci. 2017, 95, 4813-4819. [CrossRef]

30. Bluett, J.; Gimson, N.; Fisher, G.; Heydenrych, C.; Freeman, T.; Godfrey, J. Good Practice Guide for Atmospheric Dispersion Modelling; Ministry for the Environment: Wellington, New Zealand, 2004.

31. Yang, Z.; Yao, Q.; Buser, M.D.; Alfieri, J.G.; Li, H.; Torrents, A.; McConnell, L.L.; Downey, P.M.; Hapeman, C.J. Modification and validation of the Gaussian plume model (GPM) to predict ammonia and particulate matter dispersion. Atmos. Pollut. Res. 2020, 11, 1063-1072. [CrossRef]

32. Chianese, D.S.; Rotz, C.A.; Richard, T.L. Simulating methane emissions from dairy farms. In Proceedings of the American Society of Agricultural and Biological Engineers Annual International Meeting, ASABE 2008, Providence, RI, USA, 29 June-2 July 2008; p. 084098.

33. Hegarty, R.S.; Goopy, J.P.; Herd, R.M.; McCorkell, B. Cattle selected for lower residual feed intake have reduced daily methane production. J. Anim. Sci. 2007, 85, 1479-1486. [CrossRef]

34. Wlazło, Ł.; Nowakowicz-Dębek, B.; Kapica, J.; Kwiecień, M.; Pawlak, H. Removal of ammonia from poultry manure by aluminosilicates. J. Environ. Manag. 2016, 183, 722-725. [CrossRef]

35. Cottle, D.J.; Van Der Werf, J.H.J. Optimising the proportion of selection candidates measured for feed intake for a beef cattle breeding objective that includes methane emissions. J. Anim. Sci. 2017, 95, 1030-1041. [CrossRef]

36. Nowakowicz-Dębek, B.; Wlazło, Ł.; Stasińska, B.; Kułażyński, M.; Ossowski, M.; Krzaczek, P.; Bis-Wencel, H. Emission of methane from intensive pig breeding. Przem. Chem. 2017, 11, 2353-2355.

37. Wlazło, Ł.; Nowakowicz-Dębek, B.; Kałużyński, M.; Wnuk, W.; Ossowski, M. Modeling the spread of ammonia in atmospheric air around a poultry farm. Przem. Chem. 2018, 4, 645-647.

38. Commission Regulation (EU) No 601/2012 of 21 June 2012 on Monitoring and Reporting on Greenhouse Gas Emissions in Accordance with Directive 2003/87/EC of the European Parliament and of the Council. Available online: https://eur-lex.europa.eu/LexUriServ/LexUriServ.do?uri=OJ:L:2012:181:0030:0104:EN:PDF (accessed on 28 April 2019).

39. Directive 2003/35/EC of the European Parliament and of the Council of 26 May 2003 Providing for Public Participation in Respect of the Drawing up of Certain Plans and Programmes Relating to the Environment and Amending with Regard to Public Participation and Access to Justice Council Directives 85/337/EEC and 96/61/EC. Available online: https://eur-lex.europa.eu/resource.html?uri=cellar:4a80a6c9-cdb3-4e27-a721d5df1a0535bc.0004.02/DOC_1\&format=PDF (accessed on 30 April 2019).

(C) 2020 by the authors. Licensee MDPI, Basel, Switzerland. This article is an open access article distributed under the terms and conditions of the Creative Commons Attribution (CC BY) license (http://creativecommons.org/licenses/by/4.0/). 